\title{
Performativity and a microbe: Exploring Mycobacterium bovis and the political ecologies of bovine tuberculosis
}

\author{
Philip A. Robinson ${ }^{1}$ (D)
}

Published online: 6 June 2018

(C) Macmillan Publishers Ltd., part of Springer Nature 2018

\begin{abstract}
Mycobacterium bovis, the bacterium responsible for causing bovine tuberculosis (bTB) in cattle, displays what I call 'microbial performativity'. Like many other lively disease-causing microorganisms, it has an agency which is difficult to contain, and there is a need for fresh thinking on the challenges of dealing with this slippery and indeterminate microbe. As a practising veterinary scientist who side-stepped mid-career into a parallel training in the social sciences to view bTB from an alternative perspective, I create an interdisciplinary coming-together where veterinary science converges with a political ecology of (animal) health influenced by science and technology studies (STS) and social science and humanities scholarship on performativity. This suitably hybridized nexus creates a place to consider the ecologies of a pathogen which could be considered as life out of control. I consider what this means for efforts to eradicate this disease through combining understandings from the published scientific literature with qualitative interview-based fieldwork with farmers, veterinarians and others involved in the statutory bTB eradication programme in a high incidence region of the UK. This study demonstrates the value of life scientists turning to the social sciences to review their familiar professional habitus-challenging assumptions, and offering alternative perspectives on complex problems.
\end{abstract}

Keywords Bacterium - Bovine tuberculosis - Microbial ethnography · Performativity · Political ecology of health · Veterinary science

Philip A. Robinson

probinson@harper-adams.ac.uk

1 Department of Animal Production, Welfare and Veterinary Sciences, Harper Adams University,

Newport, Shropshire TF10 8NB, UK 


\section{Introduction}

Bovine tuberculosis (bTB), an infectious disease of cattle caused by the bacterium Mycobacterium bovis, continues to be an important global animal health problem. The disease is present in many parts of the world in both farmed livestock and wildlife reservoirs (Humblet et al. 2009; Hlokwe et al. 2014; Rivière et al. 2014). Although the majority of the Member States of the European Union (EU) are officially tuberculosis free, some EU countries continue to have endemic bovine disease, with the United Kingdom (UK) heading the list. Multiple risk factors for disease in cattle, badgers and other mammals in the UK have been identified (Broughan et al. 2016), but ongoing arguments over whether removing (often known as 'culling') the wildlife reservoir of badgers (Meles meles) in bovine high incidence areas is scientifically and ethically justifiable attract most attention (Woodroffe et al. 2016; Brunton et al. 2017; McCulloch and Reiss 2017).

Historically, bTB eradication programmes were primarily initiated to improve and protect human health (Jones 2004; Atkins 2016). The disease is therefore a well-known zoonosis, but the ongoing potential of $M$. bovis to infect (and kill) humans in the twenty-first century may be underestimated (Olea-Popelka et al. 2017; World Health Organization 2017). European Union legislation requires eradication of the disease (Council Directive 77/391/EEC) to facilitate the trade of animals and animal products (Council Directive 64/432/EEC), and the European Commission has previously emphasized that "EU strategy is not intended primarily to support control programmes but is focused on the achievement of the total eradication of bovine TB" (European Commission 2013, p. 4; emphasis mine).

This is not therefore an accommodation or living-with microbes and disease, but an aspiration towards complete removal of the pathogen; killing, not tolerating. Ginn et al. (2014, p. 113), discussing awkward nonhuman others, suggest that sometimes "creatures ... die so that others may live". For bTB, cattle and badgers have been killed in their thousands in the UK to reduce disease incidence over many years. Positive cattle, detected primarily through injecting avian and bovine tuberculin into the neck skin of cattle and measuring comparative immunological responses after $72 \mathrm{~h}$ (de la Rua-Domenech et al. 2006), are compulsorily removed to slaughter with compensation by the State. Badger removal, begun in England in the 1970s to prevent transmission to cattle, continues in some parts of England as part of the national disease eradication strategy (DEFRA 2014; Brunton et al. 2017).

In one region of the UK-Northern Ireland (N. Ireland) - the bTB eradication programme began in earnest in 1959 with full legislative support (Robinson 2015), but even with one of the most sophisticated bTB control systems in the world, involving a large cadre of private and state veterinarians carrying out intensive, sustained cattle testing and removal over many years, disease eradication remains elusive. Like Sisyphus in Homer's Odyssey, forever pushing the boulder to the brim of the hill only for it to roll to the bottom again (Homer 1946, p. 155), bTB just keeps on coming back. Although present in only a minority of herds at any given time [herd incidence $9.61 \%$ in 2017 (DAERA 2018)], dealing with this problem is expensive, and cost the state $£ 317$ M (US\$ 449 M) in N. Ireland between 1996 and 
2011 (NI Assembly 2012), and that does not include the private cost to farmers. Despite early promise, when the disease appeared on the verge of eradication in $\mathrm{N}$. Ireland in the late 1960s, M. bovis could be viewed as largely having 'made a shambles' of efforts to halt its spread within the cattle population of N. Ireland for nearly 60 years (Robinson 2015). This resonates with Latour's view on the difficulties of 'mastering' a microbe: "Natural objects are naturally recalcitrant; the last thing that one scientist will say about them is that they are fully masterable. On the contrary, they always resist and make a shambles of our pretentions to control" (Latour 2000, p. 116). This is sobering (and highly frustrating) for farmers and veterinarians charged with practising 'biosecurity' - the separation of microorganisms from animals - in an effort to protect livestock from infection and disease (Kelly 2005).

Plenty of attention has been paid to biosecurity and animal disease in the social science literatures, including STS, and particularly concerning highly contagious epizootic livestock diseases such as Foot-and-Mouth disease (Law 2006; Law and Mol 2008, 2010) and avian influenza (Mather and Marshall 2011; Hinchliffe and Lavau 2013). Geographers, heavily influenced by STS scholarship, have also focused on bTB biosecurity, looking in particular at farmer and veterinary attitudes and behaviours in relation to disease control (e.g. Enticott 2008a, b, 2012; Enticott et al. 2012; Atkins and Robinson 2013a, b; Robinson 2017a, b).

While lots of things come together in a complex web of causation to create bTB as a disease, including socio-political and economic contingencies (Pfeiffer 2013; Robinson 2015, 2017a, b), without the bacteria, there would be no tuberculosis. Despite the vital importance of the microbes, there has been little specific focus on the agency of these "uncooperative bacteria" (Atkins and Robinson 2013a, b) as arguably the central actors in the disease problem. This paper therefore has three main objectives. First, it seeks to re-orientate the scholarly and stakeholder analysis of bTB to focus on the bacteria as the central disease actors, rather than the animal bodies (cattle and badgers) which succumb to infection and disease; the farming, veterinary and other stakeholders who manage the animals; or the state which governs the disease eradication efforts. This objective is challenging, because as social beings, the bacteria act in concert with other things, forming associations which can be difficult to prise apart (see Mansnerus 2009; Porter 2016 for further examples of microbial (dis) entanglement). A better understanding of the agency of the bacteria is necessary if progress is to be made with the eradication campaign. In doing so, this research contributes to the literature considering the political ecologies of health which has been heavily influenced by STS approaches and theorization (Jackson and Neely 2015; Neely 2015; Robinson 2017b), and which emphasize the liveliness of more-than-human biological agents within assemblages of control (Robbins et al. 2008; Biehler 2009; Hausermann 2015). Indeed, Hausermann (2015, p. 2218) explicitly calls for critical political ecologies to "take the nonhuman seriously". Second, this focus on the agency of bacteria further expands the burgeoning literatures on the political ecologies of health by combining theoretical insights on performativity and performance with more-than-human agency to examine how pathogenic bacteria can act on multiple levels and do things to shape the world which are simultaneously natural, social, economic and political. 
The bacteria perform, but also cause other actors, both human and more-thanhuman, to perform in tandem, often causing confusion and destabilization, challenging the expertise of the human actors involved in disease control. Particularly relevant here is Schuurman and Franklin's (2015, p. 23) notion of "counterperformance", namely "resistance in a situation where it has the potential to disturb the performance or transform it". Extending conceptually beyond the consideration of counterperformance in animal-human relations takes the social theory of performance and performativity into the realm of the pathobiology and epidemiology of animal infection and disease. Third, the paper also demonstrates the value of natural scientists using STS as a medium to trace and examine "actors and actions involved across different social worlds" (Engel 2012, p. 54). In doing so, they can re-view themselves, their actions, policies, and literatures through a different (socio-political and -cultural) lens, testing long-held assumptions, and offering alternative solutions to complex scientific and socio-technical problems.

In speaking of this organism, I declare longstanding personal interest and knowledge, having worked as a veterinarian involved in seeking to control and eradicate bTB for over 20 years, employed in the front-stage scenes of the cattle farm and the abattoir, and the hinterlands of veterinary epidemiological research and policy advice, to exert what anthropologist Heather Paxson (2008) might call 'microbiopolitical control'. To adapt Hird (2009, p. 26), "I am schooled in recognizing my meetings with bacteria as military encounters-invasion.... defence [and detection] .... That is, the pathogen matrix overwhelmingly defines the parameters of animal meetings-with bacteria". Despite criticism of framing disease with the language of war, especially following Sontag's Illness as Metaphor essay (1979), my positionality as a former veterinary officer of the state means I struggle to detach myself from viewing the microbe martially as invader and 'non-self' rather than friend or 'self' (Stoller 2012). It is to be repelled and removed, rather than accepted and accommodated, but, as this paper will demonstrate, there are profound challenges inherent in attempting to discipline microbes (Ingram 2007), and militaristic framings of disease control are themselves performative, of which more will be said later.

The following section will further introduce the conceptual framework of the paper, introducing the concepts of performativity and (counter)performance as tools allowing us to re-view the agency of a bacterium and its ability to 'do things' which often disrupt and frustrate. The paper goes on to describe the research methodology, and then analyzes some of the microbe's various 'doings' on a diversity of stages. It concludes by considering what this means for the politics of bTB infection as an object and subject of state eradication, and how performativity and counterperformance provides a useful conceptual framework for scientists, policymakers and publics to re-consider the root of the matter, evaluating the challenge ahead when microbial political ecologies and non-human agency are more mindfully considered in the conduct and projected outcomes of disease eradication programmes. 


\section{Performativity and a Microbe}

Philosopher of language John Langshaw Austin, creator of the word "performative", suggested that it was "rather an ugly word", but he could find no other word to explain what he meant (Austin 1970 [1961], p. 235). Austin's focus was on utterances or speech acts which were "doing something rather than just saying something" (Austin 1970 [1961], p. 235, emphasis in original). The concept has been developed and its scope expanded and widely diversified over the intervening years to be applied across the social sciences (see Thrift and Dewsbury 2000; Loxley 2008; Faulkner 2012). The key point is that it is not solely words (Austin 1975 [1962]) that can be performative, and the emphasis on doing in performativity is the particular concern of this paper. This follows Pickering $(1995$, p. 21) in bringing "the performances - the doings—of ... material agency ... to the fore". As Sullivan suggests, "if it makes something happen, it's performative [emphasis mine]" (Sullivan 2011, p. 7).

But there is need to go beyond the consideration of microbial doings and happenings. For our purposes, we must also consider disruption, cleavage and flux, for infection and disease leading to morbidity and death are inherently disruptive processes. Further developing the themes of instability and unpredictability in performance from Gregson and Rose (2000), Schuurman and Franklin (2015) use the notion of "counterperformance" to examine friction in human-animal relationships in the context of the practices of horse training. How the horse behaves in response to the exercise of control by the trainer reflects positively or negatively on the expertise of the trainer. Notably, they delineate when the horse performs "acts of resistance which are inconsequential to the overall performance and those which are capable of destabilising the performance" (2015, p. 23). If the successful performance of statutory disease control involves eradicating a bacterium, then the power of a microbe to disrupt and destabilize not just animal bodies, but also the perceived veterinary and political expertise of the state, is worthy of further investigation.

I consider therefore the different spatial and scalar contexts of the performativity of this bacterium, looking at different performances located in the 'stuff' of the contaminated environment and in bovine and badger bodies, but also the 'surprising' and heterogeneous counterperformances characteristic (or not) of this pathogen. In considering these multiplicities, I focus on what the bacterium does, recognizing that "performativity ... involves the saturation of performances and performers with power" (Gregson and Rose 2000, p. 441). This focus provides a way to "unlock and animate new ... potentialities" of the nonhuman (Thrift and Dewsbury 2000, p. 411), and brings to the fore the everyday practices (Thrift, 1997) of a bacterium. This allows us to "examine the reality of [M. bovis] as an outcome of multiple performances that overlap and depend upon one another" (Robins 2012, p. 188). These overlaps are important, for Dewsbury (2000, p. 476) posits that "performativity is about connection. One asks what something does, and how in its doing, or being thus, it connects with other things, digresses boundaries instigating new ones, whilst rejecting, separating, and recomposing others". I bring 
performativity into the sphere of agricultural economy, and argue that this study of the entanglement between nature and culture (Harrison et al. 2004) and "nature performed" (Szerszynski et al. 2003), draws an under-rated actor from the shadows and into the spotlight. M. bovis, somewhat ironically, is often overlooked and forgotten by the stakeholders charged with, and deeply involved in, efforts to eradicate bTB.

\section{Methodology: Presentation of a Microbe}

Mycobacterium bovis is a tricky and uncertain organism; it causes a messy and political disease. I argue that, as a living biological organism, M. bovis has a "vital materiality" (Gregson et al. 2010) which resonates with Shaw's (2012, p. 613) suggestion that objects are "force-full" - "smouldering furnaces of affects that are capable of creating, policing, and destroying the very contours of existence". I do not ascribe intentional agency to the bacterium, but agency nonetheless, an agency which is perhaps akin to the "small agency" of Darwin's observations on earthworms: "Darwin describes the activities of worms as one of many 'small agencies' whose accumulated effects turn out to be quite big” (Bennett 2010, p. 96). Or, to follow another line of argument, the "material semiotics" of Law and Mol (2010, p. 58) allows intentionality and agency to be prised apart, and this bacterium can be regarded as an actor in the bTB network providing it makes "a perceptible difference". The key point here is to consider the network of humans and nonhumans collectively, for as Sayes (2014, p. 144) aptly puts it, "nonhumans do not have agency by themselves, if only because they are never by themselves". Even natural scientists recognize that bacteria and other microorganisms are social beings which form associations (Federle and Bassler 2003; Brown and Buckling 2008).

Latour (2000, p. 116) suggests that "microbes ... are utterly uninterested in what human scientists have to say about them", but to re-present $M$. bovis and re-focus on it as the central actor in bTB, I use the literatures of the natural scientists who research and describe the organism in the field and laboratory, and combine these veterinary literatures with empirical interview material. The interview data come from sixty individual and two focus-group interviews of individuals and groups of cattle farmers, veterinarians (private and state), and scientists involved with bTB in N. Ireland. These interviewees were asked about why they thought the Northern Irish programme had not yet achieved its original objective of eradication of the disease. Some were purposively selected through personal contact networks from my former employments as both private and state veterinarian in N. Ireland, and others through 'snowball' sampling (Noy 2008) the contacts of other veterinarians and farmers known to the author or through farming and veterinary gatekeepers. The interviews were semi-structured in format and were recorded with consent between September 2012 and May 2013, before full transcription and analysis using a grounded theory approach (Glaser and Strauss 2008). The overall aim was to elucidate experiences and knowledge of bTB in both high and low incidence areas within N. Ireland, and from both expert and lay perspectives. 
Multiple actors will therefore speak for the bacterium, and speak of it (or not) as they know it (or not), for it is important to know whether microbes are taken seriously by farmers and veterinarians in the field, as well as the experts in the laboratory and state veterinary offices. As Fleck (1979 [1935]) demonstrates, both 'popular' and 'journal' science can merge to generate scientific fact, and the merit of this approach to gain a range of both overlapping and contradictory opinions has been demonstrated in previous research on infectious diseases (Wallmann 1998; Wright and Nerlich 2006; Washer 2011; Jee et al. 2015). Performances require an audience, and audiences make observations on what they see and experience in the laboratory and the field.

\section{Environmental Reservoirs and Mobilities}

Dewsbury (2000, p. 475) states that "the potential the performative etches out for refusal, fracture, and torsion is set within specific sites [emphasis in original]". The agency of $M$. bovis within animal bodies is particularly relevant in the consideration of bTB, but I begin this section by considering $M$. bovis' performances in the material 'stuff' in which it lives and moves and has its being outside of the cattle who are the primary hosts of the bacterium, specifically in faeces, nasal secretions, milk and aerosols. We see here an agency of environmental resilience in varying sites and in different forms which distinguishes $M$. bovis as a difficult-to-kill pathogen, both inside and outside of its mammalian hosts.

Moore (1913, p. 99), in discussing the control of bTB through the early detection and removal of affected cattle, emphasizes that "tubercle bacteria must not be allowed to escape from any infected individual". Accepting that 'open' cases will allow bacteria to escape, he goes on to suggest that thorough disinfection of the cattle accommodation was one of the most important factors to consider in the eradication of the disease. Mycobacteria have unique cell walls which make them resistant to most antibiotics, and difficult to kill with chemical disinfectants (Scanlon and Quinn 2000). The cell wall also protects the bacterium from drying out, and it can survive for periods of weeks or months in the environment, the period dependent on ambient temperatures and exposure to sunlight (Menzies and Neill 2000). The cell walls of mycobacteria such as M. bovis are incredibly thick, and act as very efficient permeability barriers (Hoffmann et al. 2008). This gives the bacterium an aura of indestructibility, acknowledged by this research scientist:

Well, it has probably got the biggest wax coat of any sort of organism ... It will come into contact with, say, lung macrophages if it lands in the lungs. Under normal circumstances all the [chemical] reactions go on in the macrophage ... that's quite lethal to most bacteria. But the structure of mycobacteria means that they will resist that on many occasions (Int A33, research scientist).

Mycobacterium bovis is present in multiple materialities in the environment. Infected animals excrete $M$. bovis in their faeces, possibly due to bacilli from lesions in the lung being swept up the trachea in mucus and swallowed. Schroeder and 
Cotton (1907) estimated that one diseased cow passed as many as 38 million tubercle bacilli in one day in $13 \mathrm{~kg}$ of faeces. Scanlon and Quinn (2000) suggest that $M$. bovis organisms may survive for up to 6 months in slurry, and this infected slurry may then be spread on land as fertilizer, contaminating pastures as well as slurry storage tanks. Nasal secretions from infected cattle have also been found to contain M. bovis (de Kantor and Roswurm 1978), and these mucoid secretions are thought to contain the organisms from three months after infection as the animal begins to shed (Neill et al. 1991). The micro-environment of the bovine nasal cavity is a suitable place for bacterial multiplication: "It's dark, warm and moist ... it provides a good spot for it to grow" (Int A33, research scientist). Contaminated faecal ingestion is thought to be a rare source of infection in cattle (Menzies and Neill 2000), but nasal secretions shared through close bodily encounters may be more important as a means of transmission (Neill et al. 1989; Cassidy et al. 1999).

As far back as the last quarter of the nineteenth century, it was recognized that the bacteria are also excreted in milk if the diseased animal happens to have infection in the udder (Pritchard 1988). Zanini et al. (1998) state that "a typically infected udder may excrete tubercle bacteria to the extent of $5 \times 10^{2}-5 \times 10^{5}$ per $\mathrm{ml}$ of milk". Drinking raw milk was a common route of infection for humans (particularly children) and significant cause of death before the widespread introduction of milk pasteurization (Atkins 2000). Contaminated milk has even acted as a vehicle of transmission to other cattle-Houlihan et al. (2008) described an outbreak affecting calves and a farm cat where raw milk was used as an animal feeding stuff.

In addition to environmental presence linked to cattle excretion, $M$. bovis is also present in the excretions of other bTB-infected creatures. King et al. (2015) have used qPCR techniques to quantify $M$. bovis environmental presence in badger faeces, which may act as a source of infection for cattle at pasture. Even the humble earthworm has been demonstrated to ingest and move the bacteria from cattle faecal deposits, and perceivably could infect badgers through ingestion (Barbier et al. 2016). Deer, another recognized wildlife host of $M$. bovis, may also contaminate the environment and act as a vehicle of indirect transmission for cattle (Johnson et al. 2008) - their excretions into the environment are known to contaminate livestock feed and infect cattle in the USA (Palmer et al. 2004).

Moore (1913) stated that there was considerable doubt about whether cattle were more often infected through the respiratory or digestive tracts. Perceived scientific wisdom in the twenty-first century suggests that the most important and significant mobility of $M$. bovis is its carriage through the air in minute watery droplets of respiratory fluid - aerosol exhaled by diseased animals - coughed up in expulsions from the depths of the lungs. Just like the asbestos disturbed and released in demolition work to produce "an airborne dance of inextinguishable fibres" (Gregson et al. 2010, p. 1067), so the violent eruptions from the bovine respiratory tract release $M$. bovis in probably its most deadly form. Inhalation of these droplets in the air is thought to be the most common form of transmission of infection between cattle (Pollock and Neill 2002), and is also considered the main route of infection for badgers (Corner et al. 2012). Gannon et al. (2007) demonstrated in a laboratory study that M. bovis is robust in its airborne state, with $94 \%$ of bacilli 
surviving the first $10 \mathrm{~min}$ after aerosolization, and they concluded that once airborne, it can survive for prolonged periods. Such is the potency of M. bovis as an agent of disease, that only one colony-forming-unit (CFU), containing 6-10 viable bacilli, is required to initiate successful infection by the respiratory route (Dean et al. 2005). Many more bacilli are thought to be necessary to initiate bovine infection through ingestion (Menzies and Neill 2000).

The key point here is that the bacterium in its environmental state is of no particular significance in and of itself-it is doing no harm, it is merely a rod-shaped bacterium with potential infectious agency. Napier's (2012, p. 127) discussion of viruses is perhaps relevant here: "If, on its own, a virus remains inert and without locomotion, why should we privilege it with agency?" All of this materiality becomes subject to the legislative biopolitical control of the state if suspected of containing $M$. bovis - slurry can be stored on farm, and restrictions placed on where it can be spread on pasture; animal accommodation and facilities are required to be cleansed and disinfected; animals are isolated to prevent contact of excretions with others; milk is discarded from infected animals and prevented from entering the food chain. But to adopt true significance and being, to exert its most important effects from its various environmental performativities, the organisms must be inhaled (or ingested) by another animal. The rod-shaped bacterium does indeed have a damaging "colonising materiality" (Gregson, 2012, p. 2016) with a wide host range and flexibility, but it produces contrasting views between veterinarians on how dangerous that tendency to colonize may be:

It takes every possible opportunity to spread to other species and to get itself a little niche ... it seems perfectly adaptable to any situation (Int A41, state vet). The only thing that saves us from wildfire spread of the disease throughout the whole blooming country is the fact that bTB actually does not transmit that easily and readily between bovines. It happens, but if it were to happen at the same rate as some other diseases, we would be over-run (Int A42, state vet).

These movements from the environment into animal bodies are therefore confusing and difficult to adequately predict (Robinson 2017b). The bacteria in the environment can reappear in animal bodies with monotonous regularity, or wait longer backstage for an opportune moment to infect.

\section{Bovine Bodies: Performing Inside the Primary Host}

Whether infection results in a disease state in the animal depends on the interplay between the genomes of the bacterium and the infected host (Allen 2017). Much remains to be elucidated on how this plays out because of intrinsically complex immunobiology. The ability of the bacterium to 'hide' backstage in the animal and behave in an apparently indeterminate manner is highly frustrating to veterinarians and scientists. But if we take cognizance of Dewsbury, the variability in outcome of infection by itself should not particularly surprise, for "performativity is excessive ... it speaks of a multitude of possible outcomes within an event" (Dewsbury 2000, pp. 474-475). Speaking of these counterperformances (as we have already seen in 
the previous section), the human actors attribute a performative agency to the bacterium to describe its pathways and outcomes in bTB pathobiology.

What happens when that infected aerosol is inhaled by another bovine? The bacilli are most likely sucked in through the nose or mouth, but they do not stimulate the senses. Unlike Gregson's (2011, p. 151) engagements with the dust, fumes and smoke of ship breaking, which enabled her to "know this corporeally, in the throat, skin and fabric", the bacteria are carried unseen and without recognition down the trachea and into the depths of the lungs through bronchi and then bronchioles to reach the alveoli. The alveoli are the normal site of gaseous exchange to oxygenate the blood and expel carbon dioxide, but now they become the scene of immunological warfare, as the 'innate' and 'acquired' immune responses of the host seeks to defeat the microbial invader (Pollock and Neill 2002; Gupta et al. 2012). The frontline defence from the host are cells called macrophages (literally 'big eaters' from the Greek), and they engulf the bacilli to seek to destroy them. Interplay between cells is sparked by chemical messengers called cytokines as they summon help and enhance the capacity of macrophages to kill the invading nonself. Neutrophils, natural killer cells and more macrophages migrate across the blood vessels to join the attack (Gupta et al. 2012). Bactericidal gases such as nitrous oxide are released as part of the panoply of host defences. If the initial infection cannot be repelled, the acquired immune response kicks in after a number of days, and T-cells (also known as lymphocytes, a type of white blood cell) are recruited, with these cells forming the basis of immunological memory to providing defence if the invader is encountered again in the future as well as attack in the present (Pollock and Neill 2002).

The success of $M$. bovis rests in its ability to often resist the host immune responses, and to reach an entente cordiale with the host animal within the macrophage - a microbial "politics of conviviality" (Hinchliffe and Whatmore 2006) and a dwelling safe within the very cells sent to exterminate it. The infected macrophage becomes the centre of a lesion - a 'granuloma' - a cheesy abscess of dead and gradually decaying matter surrounding a bacterium which can remain very much alive, and with the ability to recrudesce months or years later. Subsequent infections with other mycobacteria have been found to 'home in' on the existing granuloma, showing that they are permeable entities - transit hubs-and do not offer protection to the host from future mycobacterial invaders (Cosma et al. 2008). The bacteria can performatively appear and re-appear, disrupting and causing confusion:

The wee beastie can hide itself away... it's intracellular, it can hide within cells, and hide in little encapsulated nodules ... for years and years and years, only to break out when the immune status of the animal has dropped below a certain point (Int A42, state vet).

There were animals that didn't show any signs of bTB, and yet they had $M$. bovis [living] up their noses-how do you explain that? (Int A33, research scientist).

Latency, the period of inactivity without progression, is considered an important feature of both bovine and human TB (Pollock and Neill 2002; Lin and Flynn 2010). 
The mycobacteria appear as if content to bide their time until exerting their destructive effects, waiting for the opportune moment to reactivate when defences are weakened through old age or a compromised immune system. Throughout this 'in-between' state of latency, like humans in remission from cancer, the infected animal is "neither sick nor cured" and in "a space that has no concrete conceptual boundaries" (Stoller 2012, p. 177) between the "normal and the pathological" (Canguilhelm 1978 [1966]). What adds to the irony is that the destruction of tissue is caused by the host itself in response to the bacterium, and the question arises as to who or what is being 'fought':

What develops within the animal or the human is really the immune response to the organism, it's not necessarily the organism which is doing the damage, it's the immune response which is damaging the animal or the human ... people look at it as if you are fighting this organism, but the damage that is being done is as much to do with the host response as it is to do with the organism itself (Int A33, research scientist).

Breakdown of the granuloma and bacterial mobilities within the body mean that new lesions can be formed and the healthy lung tissue (or whatever organ is seeded with infection) is destroyed-a slow, chronic, insidious process, but one which is very seldom seen in the developed countries today where regular animal testing removes infected animals before death would occur by much longer natural course.

The other key feature of the corporeal performativity of the bacterium is its ability to evade detection within the infected live animal, in the carcase at slaughter, and in the laboratory. Veterinarians may be viewed as the bTB experts, but what happens to that expertise when the disease has an indeterminate incubation and may take years to demonstrate its presence clinically? This is recognized by veterinarians testing in the field:

It's been able to survive in its host very nicely. It's been able to evade detection - as it does. Even on a bTB test there are 4- 6 weeks from when it gets infected [until] it's going to react to a test. And then, if it can manage to stay in an animal and wall itself off, the nasty little sod can stay out of the way, without detection by our bTB test, and then eventually at some point in time it can break out again and cause more infection to other animals (Int A40, private vet).

The tuberculin test, a skin test performed by veterinarians injecting a weakened form of $M$. bovis into the skin of a bovine to provoke an immune reaction, has been used by vets to diagnose bTB since John McFadyean published his initial experimental results in 1891 (Pattison 1984). The tuberculin test remains controversial, mistrusted and disliked by farmers and sometimes by veterinarians as well (Enticott 2012). False positives to the test (unconfirmed at slaughter or in the laboratory) decrease farmers' confidence in the expertise of the vet and the diagnostic process. False negatives, where the test fails to pick up the infection and it is later found at slaughter, seem to incur even more scorn from farmers. Farmers often have anecdotes about such cases: 
I have seen us testing and getting clear in the test and having 3 cattle... we tested on a Monday and Tuesday.... and killed [them] the following week on the Monday, Tuesday and Wednesday, and there was one animal down with bTB each day (Int A7, beef farmer).

There's been evidence a whole lot of times where men [sic] have had a clear test and then cows have gone to the abattoir and they have had bTB, so what did that tell you? ... It misses too many positive animals, that's why you've got the problem of going to the abattoir and then finding bTB when they open it up (Int A9, dairy farmer).

To make matters worse for the veterinarians and farmers, there is apparent evidence of performative co-belligerence between M. bovis and other biological species to weaken the efficacy of the tuberculin test. Experimental evidence has suggested that the parasite Fasciola hepatica (liver fluke) weakens immune responses to the test (Claridge et al. 2012) allowing M. bovis to further evade detection with the best diagnostic tool currently available. Similarly, co-infection with bovine viral diarrhoea virus (BVDV) is thought to compromise diagnostic tests, and also may potentiate susceptibility and onward transmission of infection through immunosuppression (Monies 2000; Kao et al. 2007). It appears that M. bovis is more 'nomad' than 'monad' when it comes to its inter-relations with other microbial species (Attenborough 2010). Given that infection with both liver fluke and BVDV is widespread in British cattle herds, there is cause for concern, although further investigation is required to elucidate the risks (Byrne et al. 2016, 2017).

Leaving aside the failures of the tuberculin test, other widely used detection methods also have their deficiencies. Finding animals with granulomatous lesions through visual inspection at slaughter in abattoirs is recognized as an important part of the overall surveillance regime (Olea-Popelka et al. 2012). It is though a blunt instrument of detection, bearing in mind that an animal may only have one small lesion, causing many infected animals to be missed (Corner et al. 1990). Even in the laboratory the organism is difficult to detect from tissue samples extracted at slaughter, and Medeiros et al. (2012) suggest the need for a combined approach of multiple laboratory techniques including bacteriology, histopathology, molecular and immunological detection methods to find all infected animals due to the range of stages of infection at presentation. Gallagher and Horwill (1977, p. 155) described bacteriological culture of the organism, and noted that $M$. bovis was a "fastidious" organism which "grew very poorly" in the laboratory. Identifying microbial performativity both within and beyond bovine bodies proves equally challenging.

\section{Badger Bodies: Politics and Nature Intertwined}

Rather than the bacterium, the spotlight shines particularly strongly on the agency of the badger in bTB epidemiology, and its microbial agency remains obscured from view: 
It's a bit disheartening as a young vet trying to test these animals to get them clear of diseases, and yet there's a dirty old animal [the badger] running about infecting everything (Int A17, private vet).

Attention is deflected, and the "peaceable ruminant [and particularly the badger] is suddenly transformed into a dangerous political animal that everyone should be wary of" (Callon et al. 2011, p. 1). The bacterium remains hidden within a much wider network of things.

Mycobacterium bovis is deemed most likely to enter badger bodies by inhalation, and they appear particularly susceptible to infection, leading to chronic respiratory disease and dissemination to other bodily organs over time (Corner et al. 2012; Bhuachalla et al. 2015). The significance of the badger in the spread of M. bovis in the UK and Ireland, and what to do about it, has caused much controversy both within scientific discourse, and between farmers and veterinarians ('the industry') and sceptical publics. Grant (2009) describes the inability to eradicate bTB from the English and Welsh cattle herds as an "intractable, long-term policy failure", and chronicles the succession of government review committees and reports on the subject over decades, particularly on the question of what to do about the badger. The vaccination of badgers against bTB with bacille Calmette-Guérin (BCG-a derivative of virulent $M$. bovis) is one option and is used in some parts of the UK and Ireland as part of a long-term strategy to reduce both badger and cattle incidence (Robinson et al. 2012; Aznar et al. 2018). Badger culling has been used at various times in England since the early 1970s depending on state policy (McCulloch and Reiss 2017), but is much more politically charged than vaccination. The largest field experiment ever conducted - the Randomized Badger Culling Trial (RBCT) — was led by a specially convened panel of scientists (known as the Independent Scientific Group on bovine TB-ISG) and the trial cost some $£ 49 \mathrm{M}$ (\$65M) (Cassidy 2015). This massive expenditure failed to stem the argument at both scientific and policy levels about whether to continue to cull badgers, or to refocus on cattle-to-cattle transmission. Whilst the ISG's final report on the RBCT supported the belief that badgers transmitted bTB to cattle, the overall conclusion was that "badger culling cannot meaningfully contribute to the control of cattle TB in Britain" (Bourne et al. 2007, p. 181). This conclusion provoked a storm of protest, dissent and counter-argument. The British Government's Chief Scientific Officer disagreed with the conclusion that culling was no longer a valid option, stating that "the removal of badgers could make a significant contribution to the control of cattle TB in those areas of England where there is a high and persistent incidence" (King 2007). From Ireland, More et al. (2009) questioned the RBCT evidence which suggested that perturbation of badgers caused by culling increased the risk of cattle further bTB breakdowns. Irish research suggested that badger culling was indeed a valid and effective means of reducing disease incidence in both cattle and badgers, in conflict with the British research conclusions (Olea-Popelka et al. 2009). The most recent epidemiological analysis of the current industry-led culling policy in England suggests it may have a beneficial effect on reducing cattle incidence (Brunton et al. 2017), but the controversy is likely to continue. 
On the ground, farmers' frustration and anger is typically directed towards the state on the failure to eradicate bTB, particularly on the perceived inactivity surrounding the badger issue:

Well, if the badgers have got bTB they are going to have to try and take the badgers out. Like, all my life bTB testing has been the same. Nothing extra and nothing new has ever been done. It's test every year and if something goes down, do two tests and... nothing has changed in the past 40 years [exasperated] (Int A15, dairy farmer).

Conflict predominates, with farmers pitted against the state, and the state in turn suggesting farmers could do more to help eradicate bTB, particularly by improving biosecurity on farms to try to keep infection out (Enticott 2008a). But this advice is met with apathetic responses:

If you start to say "You could maybe help yourself here-there's an awful lot farmers could be doing on biosecurity". But they [farmers] are totally disillusioned (Int A41, state vet).

Farmers, veterinarians, government policy officials and scientists engage in blame and counter-blame. For example, a private veterinarian mocked a new state initiative to search more intensively for infected herds, blaming the state (and scientists) for a lack of creative thinking:

bTB, you would say, is very lacking in science, and very lacking in in-depth stuff. Everyone is sort of floundering around with vague ideas about what is going on ... It sounds like the American Army in Afghanistan: "We're going to have a surge now on the herds around the reactor" ... I think we aren't very far down the path when that's the conclusion-that's the obvious place to check. (Int A19).

It is ironic that in the ongoing blame offensives, the microbe remains in the background, and the other human and non-human actors are thrust onto the front and centre stage. The bacterium unwittingly exerts a political agency and power to deflect blame away from itself. This is particularly relevant for the human actors, and especially the state actors charged with disease eradication, where the persistent resistance and counterperformance by the bacterium results in failure to achieve objectives, the slippage of authority, and the questioning of expertise (Schuurman and Franklin 2015).

\section{Heterogeneous Performances: Epidemiologies of Surprise}

"Materials continually have the capacity to surprise humans" state Gregson et al. (2010, p. 1081), and they remind us that "these surprises can be less than enchanting, nasty and certainly costly". Much the same can be said of M. bovis. We have seen how the material environmental and bodily performativities of the organism are varied and diffuse, but I would suggest that the epidemiological performances of the bacterium are most surprising of all. Whilst M. bovis is 
primarily a pathogen of cattle, there are surprising spillovers of infection, exhibiting a much wider potential host range than $M$. tuberculosis, its human-hosted counterpart (Allen 2017). For example, in the past decade infection has been reported in the British Isles in a dog (Shrikrishna et al. 2009), sheep (van der Burgt et al. 2012), goats (Daniel et al. 2009), alpacas (Connolly et al. 2008), cats (Roberts et al. 2014), and in a cluster of humans with no known links to agriculture (Evans et al. 2007). In cattle, occasionally most of a herd of cattle is affected, sometimes a cluster within a herd, but, somewhat paradoxically, most of the time only a single animal succumbs to infection (Menzies and Neill 2000). Transmission has been described as "an enigma" (Gannon et al. 2007) with "complexity and unpredictability" (Khatri et al. 2012). It has a mysterious mobility, and bTB is often surprising as an infectious disease; it can appear from nowhere, and leave again as quickly (Robinson 2017b). In other herds, it lingers for years without remission, but the heterogeneous performances leave farmers confounded by the multiplicity of bTB:

We haven't had any rhyme or reason on the bTB-we've had it in milk cows, an in-calf heifer, and a 9-month-old calf. (Int A24, dairy farmer).

Whether it was coincidence or not, I don't know, but we had a cow which came from England, and it was a daughter of hers which went down-and then her sister's daughter went down. There were years between them, but I found it very odd. (Int A11, dairy farmer).

I bought a cow - she was a great cow - and we had a herd test about 2 or 3 weeks after that, and that cow went down with a bang with bTB. There was a [skin] lump on her the size of your fist! And then we retested [the herd] again and everything else was clear-there was no spread of infection. (Int A13, dairy farmer).

Multiple strains of $M$. bovis circulate, and their cartographies can be elucidated through molecular typing methodologies. Some strain types are found far from their normal home range, presumably diffused as animals are moved to other farms, and yet most sources of infection seem to be local (Skuce et al. 2010). Genetically identical strains are shared between cattle and badgers in the same locality (Biek et al. 2012). There are different geographies (Abernethy et al. 2013) and histories (Atkins and Robinson 2013b) of bTB. Different herds, different age groups within a herd, different strains, different geographies, different histories of infectiondifferent, but the same-confusing ontologies, heterogeneities, different versions of disease (Enticott et al. 2012; Atkins and Robinson 2013a). This is what makes $M$. bovis even more difficult to control, for we are "thrown into the flux of an inherently mutable molecular life where reassortment is not what we control, but what we fear" (Braun 2011, p. 400). 


\section{Discussion}

This case study on the performativity of $M$. bovis demonstrates the value of natural scientists using social science to help re-view themselves and the subjects and objects of their scientific work. Indeed, Testa (2013) argues explicitly for productive integration between the life sciences and the social sciences and humanities. If, as the physicist Ziman (2001, p. 165) once suggested, research scientists are trained to "produce specialised bricks of knowledge, but not to look at the whole building", then stepping across the divide and looking back inside may well provide new vistas which enlighten and surprise when viewing scientific challenges and conundrums through new lenses. My own personal testimony as an academic veterinarian working as an interdisciplinary scholar confirms what Langlitz (2014) suggests: "recourse to other fields of inquiry enables researchers to understand and even break out of current limitations of their own knowledge cultures".

Rather than deal with the 'purified' (Latour 1993) forms and realities of bTB, I have created a hybridized political ontology of the disease, crossing the boundaries between nature and society, nature and science, human and the non-human, expert and lay expert; moving from environmental materiality and the 'stuff' of bTB, to the corporeal and political, demonstrating that the boundaries are fluid, messy and unpredictable. As Hinchliffe (2007, p. 102) argues, "the 'thing' about disease is not only the infective particle [in our case, M. bovis]; it is the relations between the various matters that make a disease". This bacterium forms relations, and has performative effects, which are powerful, contingent and often indeterminate, and operates in "performed spaces [which] are not discreet, bounded stages, but threatened, [and] contaminated" (Gregson and Rose 2000, p. 442).

Social scientists, despite their attention to the attitudes and practices of farmers and veterinarians in animal biosecurity, have arguably not focused enough on the microbial agency inside and outside of the network of animal hosts. This paper's focus on performativities has provided a framework for focusing on the "object of regulation" (Bingham and Lavau 2012) - the bacterium itself-rather than the 'doing' of biosecurity (Hinchliffe and Lavau 2013). On the other hand, veterinary scientists and policy makers, with their predominant focus on the biological aspects of bTB as a disease, have only in recent years appreciated the importance of the attitudes and resultant behaviours of the stakeholders involved in bTB eradication programmes. The pressure to make profit in competitive global agribusiness markets and resultant intensification of livestock agriculture, have contributed to the spread of $M$. bovis through husbandry practices which are less than ideal when it comes to disease eradication. Economic pressures to maximize production efficiency can result in prioritizing other important tasks, and the disciplined focus required to separate pathogenic environmental bacteria from bovines through disinfection, or keeping bovines away from badgers, or from other (potentially bTB-infected) bovines in neighbouring herds, becomes more fuzzy. As a result, the bacteria are enabled to perform in ways which enhance their ability to survive and prosper.

The performativity of $M$. bovis leads to others performing too, causing, as we have seen, controversy and conflicted framings of the disease between the state, 
scientists and stakeholders; accusation, blame and responsibility spreads through the network (Robinson 2017a, b). In this ongoing "meeting with the microcosmos" (Hird 2010), will the microbe continue to out-manoeuvre all-comers in the performance of ontological politics? As a veterinarian, the disease eradication paradigm instinctively remains in my being, and I do not propose resting content to live with the disease (Mather and Marshall 2011). But focusing on the bacteriological performativities of this organism is a stark reminder of the inherent difficulties in responding effectively "to the predicament of life out of bounds" (Clark 2013, p. 21). The task of eradication is indeed an onerous one given the inherent liveliness of this organism, but one worth the effort in continuing, albeit with renewed focus. I suggest three important lessons.

First, the place of the scientific laboratory in the bTB network needs to be reemphasized (contra Law and Mol (2011), who argue for the supremacy of the art of veterinary diagnosis in the field- "the clinic"). Although Moore and Kosut (2014, p. 536) encourage practising intraspecies mindfulness, they remind us that "animals [and to that we could add microbes] have a world that is unknown to us". There is still much that is unknown about the performativity of $M$. bovis at the scale of the microscopic, and with its endless capacity to surprise, even control is going to remain very challenging indeed. Future research in scientific laboratories might open up new vistas and give hope of brighter days to come. For example, through the development of new diagnostic technologies (Casal et al. 2014); further elucidation of complex immune responses to infection (Waters et al. 2016); effective vaccine discovery (Buddle et al. 2013); and using whole-genome sequencing to more accurately trace the spread between animals and farms (Trewby et al. 2016), we may have better tools to tackle the disease in future.

More work needs to be done to further elucidate the pathogenesis of the infection, the significance of a contaminated environment, and how specifically it is transmitted between animals. There is therefore a need to "linger in the space of the [bacterium]" (Moore and Kosut 2014, p. 517) and to study more of what van Loon (2005, p. 39) calls the "uncharted zones between the microphysics of infection and the macrophysics of epidemics". The aim in doing so is to attempt to keep one step ahead of a remarkably persistent contagion, mindful that these microbes "adhere to different topologies and comprise non-human mobilities, which frequently do not conform to the territories and networks familiar to humans' geographies" (Hodgetts and Lorimer 2015, p. 7). The danger of over-emphasizing respect for the "radical alterity and unpredictability of organisms [and] their ecologies" in what Lorimer calls the "vibrant strand of political ecology" may result in "appeals for flourishing and conviviality [which] are vague and contextspecific. They do not offer general ethical frameworks or overarching structural causes" (Lorimer 2012, p. 604). On the other hand, ignoring or underestimating the liveliness and vibrancy of matter (Bennett 2010) is also problematic. As Lorimer (2012, p. 606) counterbalances his argument, he affirms that "targets, icons and action plans are necessary, but they should give scope for non-human dynamics, multispecies deliberation and experimentation and forms of adaptive management".

Second, the militaristic language used throughout this paper is in itself performative, and considering its usefulness (or not) and consequences is 
instructive. As discussed in the introduction, veterinary meetings with pathogens are often framed as battles to be fought and won. Indeed, Hlokwe et al. (2014) ask "Are we losing the battle?" when considering the increasing intra- and interspecies transmission of $M$. bovis in South Africa. These martial framings acted as useful performative devices to bring the bacterium on stage during interviews. Veterinarians responded enthusiastically to this framing, and it encouraged them to focus on the bacterium, otherwise neglected in conversation. As a result, it was variously described as "a nasty little sod" (Int A40), "wee beastie" (Int A42), "very insidious" (Int A45), and a "clever little devil" (Int A47), and the race to beat the 'bad guy' was highlighted in this excerpt:

If it was a war situation with a live enemy they would be laughing at us. It's a bit like ' $M$ ' burrowing away for Bond, producing all these gizmos and gadgets to get one step ahead of the bad guys, except we're the good guys, and it's the bad guy (Int A41, state vet).

But if a war is taking place, who are the protagonists? Farmers never mentioned the bacterium when interviewed. The bacterium is not making war, but the veterinarians perhaps are still attempting to:

I think we are well aware of our enemy—we just can't get rid of it! [laughs] ... It's a clever organism, and I don't think we will have the science, well, not in my lifetime, to throw what we need at it to eradicate it (Int A47, state vet).

There are definite risks, for as Baehr (2006, p. 55) warns: "war language is risky, a double-edged sword, because to lose a 'war' is to bleed authority". Herein lies the problem - the 'war' against bTB in N. Ireland has been ongoing for many years, and hope of 'victory' has been all but lost, with the state blamed for failing to eradicate the disease despite the optimism of yesteryear (Robinson 2015). Although the state's battle cries may have had an effect during the Foot-and-Mouth disease crisis in 2001 (Wright and Nerlich 2006), and has been used for other national emergencies such as the Hong Kong SARS crisis of 2003 (Baehr 2006), the problem is that $M$. bovis has already penetrated and entrenched its positions across the landscape. It is not a new enemy to be feared and kept out at all costs, but is the enemy within, unseen and largely ignored. Even those who consider it, as our quote above demonstrates, believe that science and the state is effectively struggling to do anything about it. The language of war no longer exerts a useful performative effect when apathy and despair predominate:

I don't think it will ever be eradicated. I don't think so. An old vet fifty-plus years ago - my father asked him if bTB would ever be eradicated, and he said: "No, they will keep it under control, but they will never do away with it" (Int A36, dairy farmer).

Third, I suggest there is a need to widen the vista and shift the primary political focus away from predominantly concentrating on the controversies surrounding what to do about the badger. There is a need to re-focus the politics of bTB to deal with the main protagonist in all of this sorry mess - the bacterium itself. Throughout my interviews with the farmers and veterinarians in N. Ireland the bacterium was 
the one actor most readily forgotten. Even a research scientist stated half an hour into the interview: "The one thing I haven't talked about is the organism itself" (Int A33). Even if we do so, with its ultimately surprising performativities, M. bovis looks like lingering for some time to come, and it is certainly an example of "material agency" with the "negative power to resist or obstruct human projects", and which must be considered a powerful political agent (Bennett 2007, p. 113). The encore is maybe, and certainly not yet. A dose of realism must be injected into the politics, with more recognition of the "ontological instability of matter" (Braun 2008, p. 677). It is not just performance which is 'feral' (Clark 2003; Thrift and Dewsbury 2000, p. 429), but also this difficult-to-control bacterium. The human actors therefore need to work collaboratively together and stop blaming each other for the failure to completely curb the spread of this "recalcitrant microbe" (Latour 2000, p. 116).

As with ongoing efforts to eradicate polio, "the way forward is not to abandon hope about the ends but to be more realistic about the means. There are no simple solutions to the complexities of implementation ... but dealing with these complexities requires open, frank discussion" (Closser 2012, p. 399). Focusing on the performativities of $M$. bovis highlights that bTB is multiple, and the bacterium is both object (to which things are done) and subject (which does the doing) (Latimer and Miele 2013). It is a bacterium whose performances need to be brought front and centre stage once again (Goffman 1990 [1959]). Farmers, veterinarians and policy makers need to consider how farming and veterinary practices can better cope with halting the ongoing spread of, and removing, the unwelcome microbes in their midst. The danger, as Schuurman and Franklin (2015, 32) point out in a different context, is that "persistent counterperformance holds increased potential to negatively subvert the overall performance-too many incidents of counterperformance result in leakages in the performance, and control is no longer possible". A policy of continuing to test and kill the microbial hosts, by itself, looks unlikely to achieve eradication: it's time for a rethink which takes the microbes themselves more seriously. To do that, there needs to be a better acknowledgement and understanding of how they (counter) perform at their best.

Acknowledgements Grateful acknowledgement is given to Prof. Peter Atkins, Prof. Gavin Bridge and Prof. Divya Tolia-Kelly for their support throughout the course of my doctoral research. The paper was first presented at the Lived and Material Cultures Research Cluster workshop entitled Locating Performance and the Political in the Geography Department of Durham University, and the comments of the organisers and participants, particularly Prof. Paul Langley, are gratefully acknowledged. I also sincerely thank the editor and reviewers for their very helpful comments on the paper. I dedicate the paper to the late Dr Sydney Neill—a bacteriologist who knew M. bovis better than most.

Funding This research was generously funded at Durham University by a doctoral scholarship from the Department of Agriculture, Environment and Rural Affairs (DAERA) in N. Ireland. Additional funding for fieldwork expenses was provided by the Dudley Stamp Memorial Fund through the Royal Geographical Society. 


\section{References}

Abernethy, D.A., P. Upton, I.M. Higgins, G. McGrath, A.V. Goodchild, S.J. Rolfe, and S.J. More. 2013. Bovine Tuberculosis Trends in the UK and the Republic of Ireland, 1995-2010. Veterinary Record 172: 312. https://doi.org/10.1136/vr.100969.

Allen, A.R. 2017. One Bacillus to Rule Them All?-Investigating Broad Range Host Adaptation in Mycobacterium bovis. Infection, Genetics and Evolution 53: 68-76.

Atkins, P.J. 2000. Milk Consumption and Tuberculosis in Britain, 1850-1950. In Order and Disorder: The Health Implications of Eating and Drinking in the Nineteenth and Twentieth Centuries, ed. A. Fenton, 83-95. East Linton: Tuckwell Press.

Atkins, P.J. 2016. A History of Uncertainty: Bovine Tuberculosis in Britain 1850 to the Present. Winchester: Winchester University Press.

Atkins, P.J., and P.A. Robinson. 2013a. Coalition Culls and Zoonotic Ontologies. Environment and Planning A 45: 1372-1386.

Atkins, P.J., and P.A. Robinson. 2013b. Bovine Tuberculosis and Badgers in Britain: Relevance of the Past. Epidemiology and Infection 141: 1437-1444.

Attenborough, F. 2010. The Monad and the Nomad: Medical Microbiology and the Politics and Possibilities of the Mobile Microbe. Cultural Geographies 18: 91-114.

Austin, J.L. 1970. [1961] Performative Utterances. Philosophical Papers, 233-252. London: Oxford University Press.

Austin, J.L. 1975. [1962] How to do Things with Words. Oxford: Clarendon Press.

Aznar, I., K. Frankena, S.J. More, J. O’Keeffe, G. McGrath, and M.C.M. de Jong. 2018. Quantification of Mycobacterium bovis Transmission in a Badger Vaccine Field Trial. Preventive Veterinary Medicine 149: 29-37.

Baehr, P. 2006. Susan Sontag, Battle Language and the Hong Kong SARS Outbreak of 2003. Economy and Society 35: 42-64.

Barbier, E., B. Chantemesse, M. Rochelet, L. Fayolle, L. Bollache, M.L. Boschiroli, and A. Hartmann. 2016. Rapid Dissemination of Mycobacterium bovis from Cattle Dung to Soil by the Earthworm Lumbricus terrestris. Veterinary Microbiology 186: 1-7.

Bennett, J. 2007. Edible Matter. New Left Review 45: 133-145.

Bennett, J. 2010. Vibrant Matter: A Political Ecology of Things. Durham: Duke University Press.

Bhuachalla, D.N., L.A.L. Corner, S.J. More, and E. Gormley. 2015. The Role of Badgers in the Epidemiology of Mycobacterium bovis Infection (Tuberculosis) in Cattle in the United Kingdom and the Republic of Ireland: Current Perspectives on Control Strategies. Veterinary Medicine: Research and Reports 6: 27-38.

Biek, R., A. O’Hare, D. Wright, T. Mallon, C. McCormick, R.J. Orton, S. McDowell, H. Trewby, R.A. Skuce, and R.R. Kao. 2012. Whole Genome Sequencing Reveals Local Transmission Patterns of Mycobacterium bovis in Sympatric Cattle and Badger Populations. PLoS Pathogens 8 (11): e1003008. https://doi.org/10.1371/journal.ppat.1003008.

Biehler, D.D. 2009. Permeable Homes: A Historical Political Ecology of Insects and Pesticides in US Public Housing. Geoforum 40: 1014-1023.

Bingham, N., and S. Lavau. 2012. The Object of Regulation: Tending the Tensions of Food Safety. Environment and Planning A 44: 1589-1606.

Bourne, F.J., C.A. Donnelly, D.R. Cox, G. Gettinby, J.P. McInerney, W.I. Morrison, and R. Woodroffe. 2007. Bovine TB: The Scientific Evidence. Final Report of the Independent Scientific Group on Cattle TB. London: DEFRA.

Braun, B. 2008. Environmental Issues: Inventive Life. Progress in Human Geography 32: 667-679.

Braun, B. 2011. Governing Disorder: Biopolitics and the Molecularization of Life. In Global Political Ecology, ed. R. Peet, P. Robbins, and M. Watts, 389-411. London and New York: Routledge.

Broughan, J.M., J. Judge, E. Ely, R.J. Delahay, G. Wilson, R.S. Clifton-Hadley, A.V. Goodchild, H. Bishop, J.E. Parry, and S.H. Downs. 2016. A Review of Risk Factors for Bovine Tuberculosis Infection in Cattle in the UK and Ireland. Epidemiology and Infection 144: 2899-2926.

Brown, S.P., and A. Buckling. 2008. A Social Life for Discerning Microbes. Cell 135: 600-603.

Brunton, L.A., C.A. Donnelly, H. O’Connor, A. Prosser, S. Ashfield, A. Ashton, P. Upton, A. Mitchell, A.V. Goodchild, J.E. Parry, and S.H. Downs. 2017. Assessing the Effects of the First 2 years of Industry-Led Badger Culling in England on the Incidence of Bovine Tuberculosis in Cattle in 2013-2015. Ecology and Evolution 7: 7213-7230. 
Buddle, B.M., N.A. Parlane, D.N. Wedlock, and A. Heiser. 2013. Overview of Vaccination Trials for Control of Tuberculosis in Cattle, Wildlife and Humans. Transboundary and Emerging Diseases 60: 136-146.

Byrne, A.W., S. McBride, A. Lahuerta-Marin, M. Guelbenzu, J. McNair, R.A. Skuce, and S.J. McDowell. 2016. Liver Fluke (Fasciola hepatica) Infection in Cattle in Northern Ireland: A Large-Scale Epidemiological Investigation Utilising Surveillance Data. Parasites \& Vectors 9: 209. https://doi. org/10.1186/s13071-016-1489-2.

Byrne, A.W., M. Guelbenzu-Gonzalo, S.A.J. Strain, S. McBride, J. Graham, A. Lahuerta-Marin, R. Harwood, D.A. Graham, and S.J. McDowell. 2017. Assessment of Concurrent Infection with Bovine Viral Diarrhoea Virus (BVDV) and Mycobacterium bovis: A Herd-Level Risk Factor Analysis from Northern Ireland. Preventive Veterinary Medicine 141: 38-47.

Callon, M., Lascoumes, P., and Barthe, Y. 2011. Acting in an Uncertain World: An Essay on Technical Democracy (Trans: Burchell, G.). Cambridge, MA and London: The MIT Press.

Canguilhelm, G. 1978 [1966]. On the Normal and the Pathological (Trans: Fawcett, C.R.). Dordrecht, Boston, London: Reidel Publishing Company.

Casal, C., A. Díez-Guerrier, J. Álvarez, S. Rodriguez-Campos, A. Mateos, R. Linscott, E. Martel, J.C. Lawrence, C. Whelan, J. Clarke, A. O’Brien, L. Dominguez, and A. Aranaz. 2014. Strategic Use of Serology for the Diagnosis of Bovine Tuberculosis After Intradermal Skin Testing. Veterinary Microbiology 170: 342-351.

Cassidy, A. 2015. 'Big Science' in the Field: Experimenting with Badgers and Bovine TB, 1995-2015. History and Philosophy of the Life Sciences 37: 305-325.

Cassidy, J.P., D.G. Bryson, J.M. Pollock, R.T. Evans, F. Forster, and S.D. Neill. 1999. Lesions in Cattle Exposed to Mycobacterium bovis-Inoculated Calves. Journal of Comparative Pathology 121: 321-337.

Claridge, J., P. Diggle, C.M. McCann, G. Mulcahy, R. Flynn, J. McNair, S. Strain, M. Welsh, M. Baylis, and D.J.L. Williams. 2012. Fasciola hepatica is Associated with the Failure to Detect Bovine Tuberculosis in Dairy Cattle. Nature Communications 3: 853.

Clark, N. 2003. Feral Ecologies: Performing Life on the Colonial Periphery. In Nature Performed: Environment, Culture and Performance, ed. B. Szerszynski, W. Heim, and C. Waterton, 163-182. Oxford and Malden: Blackwell Publishing.

Clark, N. 2013. Mobile Life: Biosecurity Practices and Insect Globalization. Science as Culture 22: 16-37.

Closser, S. 2012. 'We Can't Give Up Now': Global Health Optimism and Polio Eradication in Pakistan. Medical Anthropology 31: 385-403.

Connolly, D.J., P.J. Dwyer, J. Fagan, M. Hayes, E.G. Ryan, E. Costello, A. Kilroy, and S.J. More. 2008. Tuberculosis in Alpaca (Lama pacos) on a Farm in Ireland, 2, Results of an Epidemiological Investigation. Irish Veterinary Journal 61: 533-537.

Corner, L.A., L. Melville, K. McCubbin, K.J. Small, B.S. McCormick, P.R. Wood, and J.S. Rothel. 1990. Efficiency of Inspection Procedures for the Detection of Tuberculous Lesions in Cattle. Australian Veterinary Journal 67: 389-392.

Corner, L.A.L., D. O’Meara, E. Costello, S. Lesellier, and E. Gormley. 2012. The Distribution of Mycobacterium bovis Infection in Naturally Infected Badgers. The Veterinary Journal 194: $166-172$.

Cosma, C.L., O. Humbert, D.R. Sherman, and L. Ramakrishnan. 2008. Trafficking of Superinfecting Mycobacterium Organisms into Established Granulomas Occurs in Mammals and is Independent of the Erp and ESX-1 Mycobacterial Virulence Loci. The Journal of Infectious Diseases 198: 1851-1855.

DAERA. 2018. Bovine TB statistics. Department of Agriculture, Environment and Rural Affairs. https:// www.daera-ni.gov.uk/sites/default/files/publications/daera/Tuberculosis\%20-\%20internet $\%$ 20monthly\%20statistics\%20-\%20January\%202018.pdf. Accessed 9 April 2018.

Daniel, R., H. Evans, S. Rolfe, R. de la Rua-Domenech, T. Crawshaw, R.J. Higgins, A. Schock, and R. Clifton-Hadley. 2009. Outbreak of Tuberculosis Caused by Mycobacterium bovis in Golden Guernsey Goats in Great Britain. Veterinary Record 165: 335-342.

Dean, G.S., S.G. Rhodes, M. Coad, A.O. Whelan, P.J. Cockle, D.J. Clifford, R.G. Hewinson, and H.M. Vordermeier. 2005. Minimum Infective Dose of Mycobacterium bovis in Cattle. Infection and Immunity 73: 6467-6471.

DEFRA. 2014. The Strategy for Achieving Officially Bovine Tuberculosis Free Status for England. April 2014. London: Department for the Environment, Food and Rural Affairs. 
de Kantor, I.N., and J.D. Roswurm. 1978. Mycobacteria Isolated from Nasal Secretions of Tuberculin Test Reactor Cattle. American Journal of Veterinary Research 39: 1233-1234.

de la Rua-Domenech, R., A.T. Goodchild, H.M. Vordermeier, R.G. Hewinson, K.H. Christiansen, and R.S. Clifton-Hadley. 2006. Ante Mortem Diagnosis of Tuberculosis in Cattle: A Review of the Tuberculin Tests, $\gamma$-Interferon Assay and Other Ancillary Diagnostic Techniques. Research in Veterinary Science 81: 190-210.

Dewsbury, J.-D. 2000. Performativity and the Event: Enacting a Philosophy of Difference. Environment and Planning D 18: 473-496.

Engel, N. 2012. New Diagnostics for Multi-drug Resistant Tuberculosis in India: Innovating Control and Controlling Innovation. BioSocieties 7: 50-71.

Enticott, G. 2008a. The Spaces of Biosecurity: Prescribing and Negotiating Solutions to Bovine Tuberculosis. Environment and Planning A 40: 1568-1582.

Enticott, G. 2008b. The Ecological Paradox: Social and Natural Consequences of the Geographies of Animal Health Promotion. Transactions of the Institute of British Geographers 33: 433-446.

Enticott, G. 2012. The Local Universality of Veterinary Expertise and the Geography of Animal Disease. Transactions of the Institute of British Geographers 37: 75-88.

Enticott, G., A. Franklin, and S. van Winden. 2012. Biosecurity and Food Security: Spatial Strategies for Combating Bovine Tuberculosis in the UK. The Geographical Journal 178: 327-337.

European Commission. 2013. Working Document on Eradication of Bovine Tuberculosis in the EU Accepted by the Bovine Tuberculosis Subgroup of the Task Force on Monitoring Animal Disease Eradication. SANCO/10067/2013, https://ec.europa.eu/food/sites/food/files/animals/docs/diseases_ erad_tb_workingdoc2006_en.pdf. Accessed 10 April 2018.

Evans, J.T., E.G. Smith, A. Banerjee, R.M.M. Smith, J. Dale, J.A. Innes, D. Hunt, A. Twedell, A. Wood, C. Anderson, R.G. Hewinson, N.H. Smith, P.M. Hawkey, and P. Sonnenberg. 2007. Cluster of Human Tuberculosis Caused by Mycobacterium bovis: Evidence for Person-to-Person Transmission in the UK. Lancet 369: 1270-1276.

Faulkner, A. 2012. Law's Performativities: Shaping the Emergence of Regenerative Medicine Through European Union Legislation. Social Studies of Science 42: 753-774.

Federle, M.J., and B.L. Bassler. 2003. Interspecies Communication in Bacteria. The Journal of Clinical Investigation 112: 1291-1299.

Fleck, L. 1979. [1935] Genesis and Development of a Scientific Fact. Chicago and London: The University of Chicago Press.

Gallagher, J., and D.M. Horwill. 1977. A Selective Oleic Acid Albumin Agar Medium for the Cultivation of Mycobacterium bovis. Journal of Hygiene 79: 155-160.

Gannon, B.W., C.M. Hayes, and J.M. Roe. 2007. Survival Rate of Airborne Mycobacterium bovis. Research in Veterinary Science 82: 169-172.

Ginn, F., U. Beisel, and M. Barua. 2014. Flourishing with Awkward Creatures: Togetherness, Vulnerability, Killing. Environmental Humanities 4: 113-123.

Glaser, B.G., and A.L. Strauss. 2008. The Discovery of Grounded Theory: Strategies for Qualitative Research. New Brunswick and London: Aldine Transaction.

Goffman, E. 1990. [1959] The Presentation of Self in Everyday Life. Harmondsworth: Penguin Books.

Grant, W. 2009. Intractable Policy Failure: The Case of Bovine TB and Badgers. The British Journal of Politics and International Relations 11: 557-573.

Gregson, N. 2011. Performativity, Corporeality and the Politics of Ship Disposal. Journal of Cultural Economy 4: 137-156.

Gregson, N. 2012. Projected Futures: the Political Matter of UK Higher Activity Radioactive Waste. Environment and Planning A 44: 2006-2022.

Gregson, N., and G. Rose. 2000. Taking Butler Elsewhere: Performativities, Spatialities and Subjectivities. Environment and Planning A 18: 433-452.

Gregson, N., H. Watkins, and M. Calestani. 2010. Inextinguishable fibres: demolition and the vital materialisms of asbestos. Environment and Planning A 42: 1065-1083.

Gupta, A., A. Kaul, A.G. Tsolaki, U. Kishore, and S. Bhakta. 2012. Mycobacterium Tuberculosis: Immune Evasion, Latency and Reactivation. Immunobiology 217: 363-374.

Harrison, S., S. Pile, and N. Thrift. 2004. Patterned Ground: Entanglements of Nature and Culture. London: Reaktion Books.

Hausermann, H.E. 2015. 'I Could Not be Idle Any Longer': Buruli Ulcer Treatment Assemblages in Rural Ghana. Environment and Planning A 47: 2204-2220. 
Hinchliffe, S. 2007. Geographies of Nature: Societies, Environments, Ecologies. London, Thousand Oaks, New Delhi, Singapore: Sage Publications Ltd.

Hinchliffe, S., and S. Whatmore. 2006. Living Cities: Towards a Politics of Conviviality. Science as Culture 15: 123-138.

Hinchliffe, S., and S. Lavau. 2013. Differentiated Circuits: The Ecologies of Knowing and Securing Life. Environment and Planning D 31: 259-274.

Hird, M.J. 2009. The Origins of Sociable Life: Evolution After Science Studies. Basingstoke and New York: Palgrave Macmillan.

Hird, M.J. 2010. Meeting with the Microcosmos. Environment and Planning D 28: 36-39.

Hlokwe, T.M., P. van Helden, and A.L. Michel. 2014. Evidence of Increasing Intra and Inter-Species Transmission of Mycobacterium bovis in South Africa: Are We Losing the Battle? Preventive Veterinary Medicine 115: 10-17.

Hodgetts, T., and J. Lorimer. 2015. Methodologies for Animals' Geographies: Cultures, Communication and Genomics. Cultural Geographies 22: 285-295.

Hoffmann, C., A. Leis, M. Niederweis, J.M. Plitzko, and H. Engelhard. 2008. Disclosure of the Mycobacterial Outer Membrane: Cryo-Electron Tomography and Vitreous Sections Reveal the Lipid Bilayer Structure. Proceedings of National Academy of Sciences 105: 3963-3967.

Homer. 1946. The Odyssey (Trans: Rieu, E.V.). London: Penguin Books.

Houlihan, M.G., F.W. Dixon, and N.A. Page. 2008. Outbreak of Bovine Tuberculosis Featuring Anergy to the Skin Test, Udder Lesions and Milkborne Disease in Young Calves. Veterinary Record 163: 357-361.

Humblet, M.F., M.L. Boschiroli, and C. Saegerman. 2009. Classification of Worldwide Bovine Tuberculosis Risk Factors in Cattle: A Stratified Approach. Veterinary Research 40: 1-24.

Ingram, M. 2007. Disciplining Microbes in the Implementation of US Federal Organic Standards. Environment and Planning A 39: 2866-2882.

Jackson, P., and A.H. Neely. 2015. Triangulating Health: Toward a Practice of a Political Ecology of Health. Progress in Human Geography 39: 47-64.

Jee, B.D., D.H. Uttal, A. Spiegel, and J. Diamond. 2015. Expert-Novice Differences in Mental Models of Viruses, Vaccines, and the Causes of Infectious Disease. Public Understanding of Science 24: 241-256.

Johnson, L.K., E. Liebana, A. Nunez, Y. Spencer, R. Clifton-Hadley, K. Jahans, A. Ward, A. Barlow, and R. Delahay. 2008. Histological Observations of Bovine Tuberculosis in Lung and Lymph Node Tissues from British Deer. The Veterinary Journal 175: 409-412.

Jones, S. 2004. Mapping a Zoonotic Disease: Anglo-American Efforts to Control Bovine Tuberculosis Before World War 1. Osiris 19: 133-148.

Kao, R.R., M.B. Gravenor, B. Charleston, J.C. Hope, M. Martin, and C.J. Howard. 2007. Mycobacterium bovis Shedding Patterns from Experimentally Infected Calves and the Effect of Concurrent Infection with Bovine Diarrhoea Virus. Journal of the Royal Society, Interface 4: 545-551.

Kelly, A.M. 2005. Veterinary Medicine in the 21st Century: The Challenge of Biosecurity. ILAR Journal 46: 62-64.

Khatri, B.L., M. Coad, D.J. Clifford, R.G. Hewinson, A.O. Whelan, and H.M. Vordermeier. 2012. A Natural-Transmission Model of Bovine Tuberculosis Provides Novel Disease Insights. Veterinary Record 171: 448. https://doi.org/10.1136/vr.101072.

King, D. 2007. Bovine Tuberculosis in Cattle and Badgers. A Report by the Chief Scientific Adviser, Sir David King, http://www.bovinetb.info/docs/RBCT_david_\%20king_report.pdf. Accessed 10 April 2018.

King, H.C., A. Murphy, P. James, E. Travis, D. Porter, Y.-J. Hung, J. Sawyer, J. Cork, R.J. Delahay, W. Gaze, O. Courtenay, and E.M. Wellington. 2015. The Variability and Seasonality of the Environmental Reservoir of Mycobacterium bovis Shed by Wild European Badgers. Scientific Reports. https://doi.org/10.1038/srep12318.

Langlitz, N. 2014. Lessons and Conversions: Reading Across Disciplinary Boundaries. BioSocieties 9: 218.

Latimer, J., and M. Miele. 2013. Naturecultures? Science, Affect and the Non-human. Theory, Culture \& Society 30: 5-31.

Latour, B. 1993. We Have Never Been Modern. Hemel Hempstead: Harvester Wheatsheaf.

Latour, B. 2000. When Things Strike Back: A Possible Contribution of 'Science Studies' to the Social Sciences. British Journal of Sociology 51: 107-123. 
Law, J. 2006. Disaster in Agriculture: Or Foot and Mouth Mobilities. Environment and Planning A 38 : 227-239.

Law, J., and A. Mol. 2008. Globalisation in Practice: On the Politics of Boiling Pigswill. Geoforum 39: 133-143.

Law, J., and A. Mol. 2010. The Actor-Enacted: Cumbrian Sheep in 2001. In Material Agency: Towards a Non-anthropocentric Approach, ed. C. Knappett and L. Malafouris, 57-77. Dusseldorf: Springer.

Law, J., and A. Mol. 2011. Veterinary Realities: What is Foot and Mouth Disease? Sociologica Ruralis 51: 1-16.

Lin, P.L., and J.L. Flynn. 2010. Understanding Latent Tuberculosis: A Moving Target. Journal of Immunology 185: 15-22.

Lorimer, J. 2012. Multinatural Geographies for the Anthropocene. Progress in Human Geography 36: 593-612.

Loxley, J. 2008. Performativity: The New Critical Idiom. London and New York: Routledge.

Mansnerus, E. 2009. The Lives of 'Facts' in Mathematical Models: A Story of Population-Level Disease Transmission of Haemophilus influenzae Type B Bacteria. BioSocieties 4: 207-222.

Mather, C., and A. Marshall. 2011. Living with Disease? Biosecurity and Avian Influenza in Ostriches. Agriculture and Human Values 28: 153-165.

McCulloch, S.P., and M.J. Reiss. 2017. Bovine Tuberculosis and Badger Control in England: Science, Policy and Politics. Journal of Agricultural and Environmental Ethics 30: 469-484.

Medeiros, L.S., C.D. Marassi, E.E.S. Figueiredo, J. Leite, A.M.R. Ferreira, and W. Lilenbaum. 2012. Assessing the Histopathology to Depict the Different Stages of Bovine Tuberculosis Infection in a Naturally Infected Herd. Brazilian Journal of Veterinary Research 32: 135-139.

Menzies, F.D., and S.D. Neill. 2000. Cattle-to-Cattle Transmission of Bovine Tuberculosis. The Veterinary Journal 160: 92-106.

Monies, R.J. 2000. Tuberculous Pneumonia and BVD in Housed Calves. Cattle Practice 8: 119-125.

Moore, V.A. 1913. Bovine Tuberculosis and its Control. Ithaca, NY: Carpenter and Company.

Moore, L.J., and M. Kosut. 2014. Among the Colony: Ethnographic Fieldwork, Urban Bees and IntraSpecies Mindfulness. Ethnography 15: 516-539.

More, S.J., T.A. Clegg, G. McGrath, J.D. Collins, L.A.L. Corner, and E. Gormley. 2009. Does Reactive Culling Lead to an Increase in Tuberculosis in Cattle? Veterinary Record 161: 208-209.

Napier, A.D. 2012. Nonself Help: How Immunology Might Reframe the Enlightenment. Cultural Anthropology 27: 122-137.

Neely, A.H. 2015. Internal Ecologies and the Limits of Local Biologies: A Political Ecology of Tuberculosis in the Time of AIDS. Annals of the Association of American Geographers 105: 791-805.

Neill, S.D., J. Hanna, J.J. O’Brien, and R.M. McCracken. 1989. Transmission of Tuberculosis from Experimentally Infected Cattle to In-Contact Calves. Veterinary Record 124: 269-271.

Neill, S.D., J.J. O'Brien, and J. Hanna. 1991. A Mathematical Model for Mycobacterium bovis Excretion from Tuberculous Cattle. Veterinary Microbiology 28: 103-109.

NI Assembly. 2012. Review into Bovine Tuberculosis, Volume 1, Together with the Minutes of Proceedings of the Committee Relating to the Summary, the Minutes of Evidence and Correspondence. Agriculture and Rural Development Committee NIA 83/11-15 13 November 2012.

Noy, C. 2008. Sampling Knowledge: The Hermeneutics of Snowball Sampling in Qualitative Research. International Journal of Social Research Methodology 11: 327-344.

Olea-Popelka, F.J., P. Fitzgerald, P. White, G. McGrath, J.D. Collins, J. O'Keefe, D.F. Kelton, O. Berke, S. More, and S.W. Martin. 2009. Targeted Badger Removal and the Subsequent Risk of Bovine Tuberculosis in Cattle Herds in County Laois, Ireland. Preventive Veterinary Medicine 88: 178-184.

Olea-Popelka, F., Z. Freeman, P. White, E. Costello, J. O’Keefe, K. Frankena, W. Martin, and S. More. 2012. Relative Effectiveness of Irish Factories in the Surveillance of Slaughtered Cattle for Visible Lesions of Tuberculosis, 2005-2007. Irish Veterinary Journal 65: 2.

Olea-Popelka, F., A. Muwonge, A. Perera, A.S. Dean, E. Mumford, E. Erlacher-Vindel, S. Forcella, B.J. Silk, L. Ditiu, A. El Idrissi, M. Raviglione, O. Cosivi, P. LoBue, and P.I. Fujiwara. 2017. Zoonotic Tuberculosis in Human Beings Caused by Mycobacterium bovis-A Call for Action. Lancet Infectious Diseases 17: e21-e25.

Palmer, M.V., W.R. Waters, and D.L. Whipple. 2004. Investigation of the Transmission of Mycobacterium bovis from Deer to Cattle Through Indirect Contact. American Journal of Veterinary Research 65: 1483-1489.

Pattison, I. 1984. The British Veterinary Profession, 1791-1948. London: JA Allen. 
Paxson, H. 2008. Post-Pasteurian Cultures: The Microbiopolitics of Raw-Milk Cheese in the United States. Cultural Anthropology 23: 15-47.

Pfeiffer, D.U. 2013. Epidemiology Caught in the Causal Web of Bovine Tuberculosis. Transboundary and Emerging Diseases 60: 104-110.

Pickering, A. 1995. The Mangle of Practice: Time, Agency, and Science. Chicago and London: The University of Chicago Press.

Pollock, J.M., and S.D. Neill. 2002. Mycobacterium bovis Infection and Tuberculosis in Cattle. Veterinary Journal 163: 115-127.

Porter, N. 2016. Ferreting Things Out: Biosecurity, Pandemic Flu and the Transformation of Experimental Systems. BioSocieties 11: 22-45.

Pritchard, D.G. 1988. A Century of Bovine Tuberculosis 1888-1988: Conquest and Controversy. Journal of Comparative Pathology 99: 357-399.

Rivière, J., K. Carabin, Y. Le Strat, P. Hendrikx, and B. Dufour. 2014. Bovine Tuberculosis Surveillance in Cattle and Free-Ranging Wildlife in EU Member States in 2013: A Survey-Based Review. Veterinary Microbiology 173: 323-331.

Robbins, P., R. Farnsworth, and J.P. Jones III. 2008. Insects and Institutions: Managing Emergent Hazards in the U.S. Southwest. Journal of Environmental Policy \& Planning 10: 95-112.

Roberts, T., C. O'Connor, J. Nunez-Garcia, R. de la Rua-Domenech, and N.H. Smith. 2014. Unusual Cluster of Mycobacterium bovis Infection in Cats. Veterinary Record 174: 326.

Robins, R. 2012. The Controversy over GM Canola in Australia as an Ontological Politics. Environmental Values 21: 185-208.

Robinson, P.A. 2015. A History of Bovine Tuberculosis Eradication Policy in Northern Ireland. Epidemiology and Infection 143: 3182-3195.

Robinson, P.A. 2017a. Farmers and Bovine Tuberculosis: Contextualising Statutory Disease Control Within Everyday Farming Lives. Journal of Rural Studies 55: 168-180.

Robinson, P.A. 2017b. Framing Bovine Tuberculosis: A 'Political Ecology of Health' Approach to Circulation of Knowledge(s) About Animal Disease Control. The Geographical Journal 183: 285-294.

Robinson, P.A., L.A.L. Corner, E.A. Courcier, J. McNair, M. Artois, F.D. Menzies, and D.A. Abernethy. 2012. BCG Vaccination Against Tuberculosis in European Badgers (Meles meles): A Review. Comparative Immunology, Microbiology and Infectious Diseases 35: 277-287.

Sayes, E. 2014. Actor-Network Theory and Methodology: Just What Does it Mean to Say that Nonhumans have Agency? Social Studies of Science 44: 134-149.

Scanlon, M.P., and P.J. Quinn. 2000. Inactivation of Mycobacterium bovis in Cattle Slurry by Five Volatile Chemicals. Journal of Applied Microbiology 89: 854-861.

Schroeder, E.C., and Cotton, W.E. 1907. The danger from tubercle bacilli in the environment of tuberculous cattle Bulletin No. 99. Washington, DC: United States Department of Agriculture Bureau of Animal Industry.

Schuurman, N., and A. Franklin. 2015. Performing Expertise in Human-Animal Relationships: Performative Instability and the Role of Counter Performance. Environment and Planning D 33: 20-34.

Shaw, I.G.R. 2012. Towards an Evental Geography. Progress in Human Geography 36: 613-627.

Shrikrishna, D., R. de la Rua-Domenech, N.H. Smith, A. Colloff, and I. Coutts. 2009. Human and Canine Pulmonary Mycobacterium bovis Infection in the Same Household: Re-emergence of an Old Zoonotic Threat? Thorax 64: 89-91.

Skuce, R.A., T.R. Mallon, C.M. McCormick, S.H. McBride, G. Clarke, A. Thompson, C. Couzens, A.W. Gordon, and S.W. McDowell. 2010. Mycobacterium bovis Genotypes in Northern Ireland: herdlevel surveillance (2003 to 2008). Veterinary Record 167: 684-689.

Sontag, S. 1979. Illness as Metaphor. London: Allen Lane.

Stoller, P. 2012. Immunology and the Between. Cultural Anthropology 27: 175-180.

Sullivan, R. 2011. Geography Speaks: Performative Aspects of Geography. Farnham and Burlington: Ashgate Publishing Ltd.

Szerszynski, B., W. Heim, and C. Waterton. 2003. Nature Performed: Environment, Culture and Performance. Oxford and Malden, MA: Blackwell Publishing.

Testa, G. 2013. European Lives: New Vistas Across the Social Sciences and Biomedical Humanities. In: Horizons for Social Sciences and Humanities Conference Report. Vilnius, pp. 64-68.

Thrift, N. 1997. The Still Point: Resistance, Expressive Embodiment and Dance. In Geographies of Resistance, ed. S. Pile and M. Keith, 124-151. London and New York: Routledge. 
Thrift, N., and J.-D. Dewsbury. 2000. Dead Geographies and How to Make Them Live. Environment and Planning D 18: 411-432.

Trewby, H., D. Wright, E.L. Breadon, S.J. Lycett, T.R. Mallon, C. McCormick, P. Johnson, R.J. Orton, A.R. Allen, J. Galbraith, P. Herzyk, R.A. Skuce, R. Biek, and R.R. Kao. 2016. Use of Bacterial Whole-Genome Sequencing to Investigate Local Persistence and Spread in Bovine Tuberculosis. Epidemics 14: 26-35.

van der Burgt, G.M., F. Drummond, T. Crawshaw, and S. Morris. 2012. An Outbreak of Tuberculosis in Lleyn Sheep in the UK Associated with Clinical Signs. Veterinary Record 172: 69.

van Loon, J. 2005. Epidemic Space. Critical Public Health 15: 39-52.

Wallmann, S. 1998. Ordinary Women and Shapes of Knowledge: Perspectives on the Context of STD and AIDS. Public Understanding of Science 7: 169-185.

Waters, W.R., M.F. Maggioli, M.V. Palmer, T.C. Thacker, J.L. McGill, H.M. Vordermeier, L. BerneyMeyer, W.R. Jacobs, and M.H. Larsen. 2016. Interleukin-17A as a Biomarker for Bovine Tuberculosis. Clinical and Vaccine Immunology 23: 168-180.

Washer, P. 2011. Lay Perceptions of Emerging Infectious Diseases: A Commentary. Public Understanding of Science 20: 506-512.

Woodroffe, R., C.A. Donnelly, C. Ham, S.Y.B. Jackson, K. Moyes, K. Chapman, N.G. Stratton, and S.J. Cartwright. 2016. Badgers Prefer Cattle Pasture But Avoid Cattle: Implications for Bovine Tuberculosis Control. Ecology Letters 19: 1201-1208.

World Health Organisation. 2017. Global Tuberculosis Report. Geneva: World Health Organisation.

Wright, N., and B. Nerlich. 2006. Use of the Deficit Model in a Shared Culture of Argumentation: the Case of Foot and Mouth Science. Public Understanding of Science 15: 331-342.

Zanini, M.S., E.C. Moreira, M.T. Lopes, P. Mota, and C.E. Salas. 1998. Detection of Mycobacterium bovis in Milk by Polymerase Chain Reaction. Journal of Veterinary Medicine Series B 45: 473-479.

Ziman, J. 2001. Getting Scientists to Think About What They are Doing. Science and Engineering Ethics 7: $165-176$.

Dr Philip A. Robinson is a Principal Lecturer in Farm Animal Health and Welfare at Harper Adams University. He is recognized by the Royal College of Veterinary Surgeons in the United Kingdom as a Specialist in State Veterinary Medicine, and has been involved in bovine tuberculosis (bTB) control since his veterinary career began in 1997 . He previously worked as a veterinarian in private general practice before becoming a state veterinary officer and then veterinary epidemiologist in Northern Ireland. He completed his Ph.D. on bTB in the Geography Department of Durham University. 